This article was downloaded by: [Australian National University Library]

On: 21 February 2011

Access details: Access Details: [subscription number 907447645]

Publisher Routledge

Informa Ltd Registered in England and Wales Registered Number: 1072954 Registered office: Mortimer House, 3741 Mortimer Street, London W1T 3JH, UK

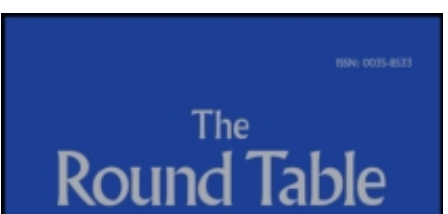

\title{
The Round Table
}

Publication details, including instructions for authors and subscription information:

http://www.informaworld.com/smpp/title $\sim$ content=t713448095

\section{A New Era for EU-Australia Relations? Sustainable Development and the Challenge of Climate Change as Litmus Test}

Karen Hussey; Simon Lightfoot ${ }^{\mathrm{b}}$

${ }^{a}$ Australian National University, Canberra, Australia ${ }^{\text {b }}$ University of Leeds, Leeds, UK

Online publication date: 15 October 2010

To cite this Article Hussey, Karen and Lightfoot, Simon(2010) 'A New Era for EU-Australia Relations? Sustainable Development and the Challenge of Climate Change as Litmus Test', The Round Table, 99: 410, 503 - 513

To link to this Article: DOI: 10.1080/00358533.2010.509952

URL: http://dx.doi.org/10.1080/00358533.2010.509952

\section{PLEASE SCROLL DOWN FOR ARTICLE}

Full terms and conditions of use: http://www.informaworld.com/terms-and-conditions-of-access.pdf

This article may be used for research, teaching and private study purposes. Any substantial or systematic reproduction, re-distribution, re-selling, loan or sub-licensing, systematic supply or distribution in any form to anyone is expressly forbidden.

The publisher does not give any warranty express or implied or make any representation that the contents will be complete or accurate or up to date. The accuracy of any instructions, formulae and drug doses should be independently verified with primary sources. The publisher shall not be liable for any loss, actions, claims, proceedings, demand or costs or damages whatsoever or howsoever caused arising directly or indirectly in connection with or arising out of the use of this material. 


\title{
A New Era for EU-Australia Relations? Sustainable Development and the Challenge of Climate Change as Litmus Test
}

\author{
KAREN HUSSEY* AND SIMON LIGHTFOOT** \\ *Australian National University, Canberra, Australia \\ **University of Leeds, Leeds, UK
}

\begin{abstract}
The election of the Labor government in 2007 appeared to usher in a new era of EU-Australian relations with a greater focus on those areas of agreement between Australia and the EU. This paper therefore explores the potential for closer cooperation between the EU and Australia in the area of sustainable development. It takes climate change as a 'litmus test' for the EU-Australia relationship due to the prominence given to the issue by both the EU and Australia and the contentious nature of the issue in relations between the EU and Australia under the previous government. After outlining the major tenets of the 'new era' under the Rudd government, those areas of policy divergence and convergence and thus opportunities for closer cooperation are highlighted and the residual issues that could offer opportunities for closer cooperation. It is concluded that these residual issues hinder developments in the relationship, but more signs of a new relationship are seen than previously.
\end{abstract}

KEY WORDS: European Union, Australia, sustainable development, climate change, trade and environment, Copenhagen Summit

\section{Introduction}

The election of Kevin Rudd's Labor government in $2007^{1}$ appeared to usher in a new era of EU-Australian relations. Talk of a new era, indeed of a 'revitalised' relationship, promises to look beyond divergent views on agriculture and focus instead on collaborating on major issues such as counter-terrorism and nonproliferation, climate change and energy security, and trade liberalisation and the strengthening of the multilateral trading system. In international relations terms, the rhetoric is certainly very promising. However, the extent to which a stronger, closer relationship can be realised beyond mere rhetoric - and the aims of such an alliance achieved - will rely on the ability of the two actors to work closer together to pursue 
shared aims, which in turn depends on the level of policy convergence that already exists, or can be achieved, in the areas identified as important to the relationship (Busch and Jorgens, 2005). The purpose in this paper, therefore, is to explore the potential for closer cooperation between the EU and Australia in the area of sustainable development, specifically in relation to the challenge of climate change.

The paper is divided in the following way. First, the major tenets of the 'new era' under the Rudd government are outlined, specifically in relation to the Framework Partnership. Second, the relationship is 'unpacked' in the area of sustainable development and climate change, exploring, in turn, the areas of policy divergence, evidence of policy convergence and thus opportunities for closer cooperation and the residual issues that could offer opportunities for closer cooperation. Overall, the implications of the case study for the EU-Australia relationship are discussed more broadly, and specifically the extent to which we do indeed find ourselves in a new era. It is to this question that the paper now turns.

\section{A Framework for Partnership: Evidence of a New Era?}

Kenyon and Kunkel suggest that the EU and Australia suffer from what they refer to as 'residualism'; essentially, each partner relates to the other only after 'policymakers have exhausted themselves engaging with, inter alia, their immediate region, the United States, the economic giants of North Asia, the developing world, etc. etc.' (Kenyon and Kunkel, 2005, p. 63). In the 1990s and through to the early 2000s, the 'residualism' in EU-Australian relations started to thaw somewhat, with Australian policy-makers beginning to appreciate the impacts of both European integration and the single market. As a result, there were far more compelling reasons for Australia to engage with the EU as a block rather than on a bilateral basis with each of the member states. The EU's deepening integration and prominence in the international arena has seen a shift in Australia's policy towards the EU, and interestingly the groundwork for Rudd's 'reinvigorated relationship' had been laid in the 1990s.

It was clear that, at least on a balance sheet, Kevin Rudd inherited a relatively healthy relationship with the EU (see Murray, 2005). Nevertheless, both political and scholarly commentators continued to lament the lack of any great enthusiasm towards the EU during the Howard years (Kenyon and Kunkel, 2005; Murray, 2005; Raffin, 2007), thus when the Rudd government was elected in 2007 an opportunity existed to build on the existing links and refocus the relationship away from their differences and towards their commonalities (Dobell, 2008). Of course, Rudd's foreign policy emphasis on multilateral diplomacy very much mirrors the EU's approach to foreign policy, with Barroso stating that 'we have certainly noticed with satisfaction the emphasis the Prime Minister is placing on effective multilateralism' (Barroso interview, April 2008).

The foundation upon which the Rudd government is basing the new EUAustralia relationship is the European Union-Australia Partnership Agreement (CEC, 2009). In contrast to the 1997 Joint Declaration and the 2003 Agenda for Cooperation, the 2008 Framework Partnership is very broad in scope and comprehensive in detail, running to 15 pages and no less than 46 immediate actions'. The Partnership Agreement sets out five objectives: 
(1) Strengthening bilateral and multilateral dialogue and cooperation in support of shared foreign policy and security interests.

(2) To promote and support a multilateral rules-based trading system, and consolidate and expand the bilateral trade and investment relationship.

(3) To enhance bilateral and regional cooperation and coordination between Australia and the EU in relation to the Asia and Pacific regions.

(4) To seek opportunities to cooperate on climate change, environment, energy security, fisheries and forestry.

(5) To strengthen cooperation between the EU and Australia in science, research, technology and innovation, education and culture and to facilitate the movement of people.

The purpose in this paper is to explore the potential for closer cooperation between the EU and Australia in the area of sustainable development, specifically in relation to the challenge of climate change. The reason for choosing climate change as a 'litmus test' for the EU-Australia relationship more broadly is threefold: first, cooperation in the area of climate change was identified as an area of key importance in the 2008 EU-Australia Partnership Framework; second, climate change and global environmental governance more generally has been an area of contention between the two in recent years and thus represents a more difficult domain for cooperation than, for instance, counter-terrorism or nuclear non-proliferation; and third, the success of international efforts to develop an effective, comprehensive post2012 global agreement on climate change depends on a high degree of international cooperation among the negotiating parties, and thus the capacity for the EU and Australia to support each other's positions in the United Nations Framework Convention on Climate Change (UNFCCC) will have very real implications for the development of an international agreement on climate change. An additional element is the change of administration in the United States, which has changed the rhetoric on climate change, in particular. Previously, Australia, to a large extent, has been able to hide behind the United States' position on climate change (Elliott, 2001b), but the positional change in the United States now means that the spotlight is on states such as Australia, particularly in the run up to the UN negotiations in Copenhagen in December 2009. In the next section, we explore the evolving policy positions in the EU and Australia in the area of sustainable development and climate change, highlighting the 'divergence' and 'convergence' that has taken place over the last decade or so. In a final, important section we highlight the gap between rhetoric and reality in that convergence and, particularly, the constraints the Rudd government faced in the domestic setting.

\section{Case Study as Litmus Test: Convergence or Divergence in Sustainable Development and the Challenge of Climate Change}

The signing of the Partnership Framework, very senior-level delegations to Brussels so early in the Rudd government's tenure, and the appointment of Dr Nelson as 'Rudd's man on the ground in Europe', are all clear indicators of a new, enthusiastic approach to the EU-Australia relationship. However, the extent to which a stronger, 
closer relationship can be realised - and the aims of such an alliance achieved - will rely on the ability of the two actors to work closer together to pursue shared aims, which in turn depends on the level of policy convergence that already exists, or can be achieved, in the areas identified as important to the relationship (see Busch and Jorgens, 2005).

The concept of sustainable development is seen to express essential normative standards for a global ethics of environment-and-development (Lafferty, 1997, p. 187). At the heart of this definitional process has been the much utilised definition outlined in the Brundtland Report, which defines sustainable development as 'development that meets the needs of the present without compromising the ability of future generations to meet their own needs' (World Commission on Environment and Development (WCED), 1987, p. 43). To meet this definition, the concept has been given relatively specific and wide-ranging operational goals, as well as structures for realising these goals (Lafferty, 1997, p. 187). Therefore, following the Rio Summit in 1992, we can identify multilateral environmental agreements that operationalise the specific norm of sustainable development as developed through the WCED: Principle 1 of the 1992 United Nations Conference on Trade and Development Rio Declaration; the Convention on Biological Diversity (1992); the UNFCCC (1992) and the resultant Kyoto Protocol (1997); and the Cartagena Protocol on Biosafety (2000). Taken separately, Australia and the EU's engagement with these international environmental negotiations is interesting, but it is where the two intersect that is of particular interest for the EU-Australia relationship.

With the exception of the United States, there is perhaps no other developed country in the world that has taken exception to the EU as demandeur more than Australia. The two entities have approached 'sustainable development' very differently after initial convergence in the early 1990s, and their policy instruments are markedly different at national and international levels. The EU's interpretation of sustainable development that can be found in its laws and treaties bears resemblance to the norm formulated by Brundtland, the same norm that Australia appeared to be moving away from under Howard (Baker, 2005, p. 147; Brande, 2009). But how is the EU's agenda perceived by Australia? It is therefore instructive to examine the two broad areas where the EU's desire to mould global environmental governance in its own image can be placed in sharp relief to Australia's alternative vision for sustainable development: the design and implementation of an effective climate change mitigation regime; and the place of environmental issues in the world trade system. We explore each of these in turn to highlight how the EU and Australia differ in their approaches, how that in turn links back to the Brundtland norm of sustainable development, and, ultimately, to draw conclusions for the EU-Australia relationship.

\section{Divergence}

Australia's original endorsement of the Brundtland Commission's definition of sustainable development saw it offer leadership in the field of climate change, in stark contrast to the EU's initially reluctant participation in the Montreal Protocol on the Depletion of the Ozone Layer (Oberthür and Kelly, 2008; Costa, 2008). 
However, by the mid-1990s the pendulum was beginning to swing, with growing concerns in both the Australian Labor Party and the Liberal Party as to Australia's ability to meet its obligations under the UNFCCC. By the time the first Conference of the Parties took place in Berlin, in 1995, Australia had undertaken a significant reversal of its previous policy position (McDonald, 2005, pp. 223-224). During the period of the Howard government, two fundamental issues where the two entities differed were highlighted: first, in relation to 'differentiation' among states; and second, in the setting of targets and deadlines for international obligations. Australia and the EU in the period of study pursued different strategies to tackle climate change. Although Australia initially signed the Kyoto Protocol in 1998, it subsequently refused to ratify it in 2002 because it was no longer deemed to be in the 'national interest' (McDonald, 2005; Cass, 2008; Stevenson, 2009). The EU, on the other hand, has not only ratified the Kyoto Protocol but it has also emerged as a leader in the UNFCCC negotiations (Baker, 2006). Owing, in part, to its large brown coal production, Australia has the largest greenhouse gas (GHG) emissions per capita, and an economy that relies heavily on GHG emission industries. This fact saw it vigorously negotiate for the so-called 'Australia clause' in the early negotiations of the UNFCCC. Australia's target under the Kyoto Protocol is a $108 \%$ increase in GHG emissions on 1990 levels by the 2008-12 commitment period (McDonald, 2005). ${ }^{2}$ Thus, Australia emphasised the role of technology and science in solving the climate change problem, and was a strong supporter of carbon sinks, emissions trading and technological transfer to tackle carbon emissions (Papadakis, 2002).

The Howard government also argued against the design of the Kyoto Protocol in relation to 'differentiation' (see Grant and Papadakis, 2004; McDonald, 2005). 'Differentiation' refers to the principle of 'common but differentiated responsibility', meaning that the overall goal is common but that the targets for achieving that goal would be differentiated across states, depending on various factors. In the context of the Kyoto Protocol, this referred to the engagement of developing countries in reducing carbon emissions (Papadakis, 2002). The EU argued that the current problem of global warming was a result of the developed world's industrialisation and thus the costs should not be borne by the developing world. By contrast, Australia argued that no climate change regime would be worth signing without a clearly defined, but appropriately lenient, commitment from future, significant emitters such as China and India. The Australian Prime Minister John Howard summed up the differences in a 2005 paper, stating 'We believe a meaningful response to climate change requires commitment and action by all major emitters, not just the most-industrialised countries ...' (Howard, 2005, p. 80). Australia considered the EU's position to be hypocritical given the EU's own use of differentiation in the development of the EU 'bubble', which saw Portugal, Ireland, Greece and Spain given significant lenience in relation to reducing carbon emissions within the EU, but being part of the regime none the less (see Oberthür and Kelly, 2008). Thus, the Australian position was that as:

... the Protocol does not include commitments from developing countries and the United States has said that it will not ratify. So not all major emitters are engaged. Ratification by Australia could risk Australia's emission-intensive 
industries facing costs that their overseas competitors do not. (DFAT, 2003, p. 67)

Interestingly, and despite its reluctance to ratify the Kyoto Protocol, the Howard government was committed to, and met, the target set in 1998. It has also launched the Asia-Pacific Partnership for Clean Development and Climate (APP), where Australia worked with the United States, China, India and South Korea to try and solve climate change outside the Kyoto framework (Kellow, 2006; McGee and Taplin, 2006). A second point of contention between the EU and Australia in relation to international environmental agreements in general lay in the setting of targets and deadlines. For Australia, the EU's insistence on 'unrealistic' targets that distribute the burden of responsibility unequally were opposed because they could unduly burden the Australian economy. The perception of the EU's position in Canberra was that the EU would prefer an ambitious target even if most would fail to reach that target. By contrast, Australia preferred realistic targets that were 'practical' and 'achievable' (Elliott, 2001a).

The other major issue was the trade-environment nexus. The European Commission has been very active in trying to make the rules that govern the world trading system better reflect the need for environmental protection. In the 1990s, two rulings (the 'shrimp-turtle' and 'tuna-dolphin' cases) in the World Trade Organisation (WTO) dispute settlement body opened the door for such a rewriting as they confirmed that potentially trade-restricting practices could be used in the interests of environmental protection (see DeSombre and Barkin, 2002). The EU has been pushing for the trade-distorting provisions of some Multilateral Environmental Agreements (MEAs) to be allowable in the interests of environmental protection, even though they contravene WTO regulations (Eckersley, 2004). Australia, along with the vast majority of WTO members, argued that WTO rules should not be changed to accommodate the trade measures contained in MEAs, but the EU consistently pursued the issue and successfully pushed for its inclusion in the mandate of the Doha Development Round, in return for concessions in the agricultural sector (Vogler, 2005).

This EU's use of its economic and political weight in the international trading system was seen by Australia as an attempt by the EU to

...advance regulatory regimes that are modeled on its own domestic arrangements. Such arrangements can, if applied globally, be excessively prescriptive and often unnecessarily costly to implement, and they may not always result in significant environmental outcomes. (DFAT, 2003, p. 67)

In short, Australia's policy under the Coalition government was simple: whatever the objective, do not use the trading system to achieve it (Oxley, 2002).

A related issue is the EU's attempts to ensure that the precautionary principle gains greater recognition from the WTO (Kenyon and Kunkel, 2005, p. 64). Australia and the EU had different interpretations of the principle's status in international law. The EU accorded certain legal implications to the principle via its treaties and Article 174(2), ${ }^{3}$ such that the precautionary principle is one of the principles to be taken into account in community policy on the environment, in 
addition to its application for human, animal and plant health (Baker, 2006, pp. 8588). In Australia, precaution has been seen as an approach rather than a principle, which meant it did not accept that it has the status of customary international law (see Pallemaerts, 2003, p. 8). Australia was concerned that the EU's moves to apply the principle universally would mean that countries could use the precautionary principle as a protectionist trade measure, thus damaging Australia's export interests (DFAT, 2003, p. 67). Moreover, there was considerable debate over the issue at the 2002 World Summit on Sustainable Development, with many commentators suggesting that Australia was willing to renege on previous commitments and that it was only through EU pressure that the principle was reaffirmed (see Burchell and Lightfoot, 2004; Lightfoot, 2006).

\section{Convergence?}

The election of the Rudd government appears to signal a shift in environmental policy, especially on climate change, in Australia. McGee and Taplin (2009) argue that the deregulatory ecological modernisation discourse of the previous administration has lost ground compared with a re-engagement with discourses supportive of developed country emission reduction targets and equity-based adaptation and technology transfer assistance for developing nations. Indeed, one of Rudd's first acts was to sign the Kyoto Protocol, signalling a return to multilateralism, which was welcomed by the EU. While signing Kyoto may have been an easy way to signal a break with the past on this issue, Rudd set out an ambitious strategy to 'unite the world on climate change' by using Australia's new position as a member of the Kyoto club to 'bridge the gap' between developed and developing countries on future emissions controls. The Labor government has also put forward domestic policy initiatives such as emission reduction targets and legislation has been drafted for an Emission Trading Scheme (ETS) and Renewable Energy Target, both of which are very similar to EU schemes suggesting evidence of convergence. Likewise, the European Commission has signed up for the Carbon Capture and Storage Institute, which is an Australian initiative. Interestingly though, the Rudd government has made a decision to continue involvement with the APP. This decision is a pragmatic one due to the links it provides to China and India (Lawrence, 2009). We have also seen Climate Change Minister Penny Wong propose voluntary carbon cuts in developing countries that can be progressed on 'national schedules', which appears very similar to the EU bubble negotiated at Kyoto, another sign of policy convergence.

Prior to Copenhagen, Rudd was extremely active in trying to bring together a coalition behind his plans for a new climate change framework. At the Commonwealth Heads of Government meeting in Trinidad and Tobago in November 2009, he was particularly successful at achieving agreement among the Commonwealth leaders, in particular in getting support from the Commonwealth developing countries, whose support it was felt would be necessary to obtain a deal in Copenhagen. In an agreement unveiled by Mr Rudd, there was agreement on a carbon-credit trading scheme and push for wealthier countries to pay developing nations to help them with the costs of new environmentally friendly policies. This consensus among Commonwealth leaders was seen as the 'high point' of the meeting, 
and it was felt that it would 'add some momentum to the Copenhagen talks'. However, 'it was also argued that the consensus was limited in ambition as it containing $[s i c]$ no targets for cutting greenhouse gas emissions' (Pearce, 2009).

As per Objective 4 of the new Framework, both the EU and Australia promised emission reductions of between 25 and $30 \%$. These targets, especially the Australian ones, were criticised for being no better than a 'greenwashed version of the old Kyoto plan' due to the conditions that the government appeared to link to the target (Pearce, 2009). However, in the event, the pre-summit statements that both the EU and Australia were key to the success of the Copenhagen talks proved wide of the mark. The final agreement was the result of a deal between the United States, China, India and South Africa, one that saw the EU and Australia sidelined diplomatically.

Both Australia and the EU were seen as having had a 'bad summit'. Domestic pressures on the Rudd government, such as the need for Liberal Party support in the Senate and opposition from many of the large $\mathrm{CO}_{2}$-emitting industries to plans for an ambitious carbon-trading scheme ${ }^{4}$, and the strong belief in multilateralism, meant that Rudd needed the Summit to deliver (Craft, 2009). The Economist argues that few leaders have staked more on tackling climate change than Rudd (Economist, 1 May 2009). Indeed, the government has put off its Carbon Pollution Reduction Scheme (CPRS) until at least 2013, blaming frustrations in the Senate and the lack of climate change action globally, at Copenhagen. There is still the chance that the forthcoming election in Australia could be the 'climate change election', owing to the choice of the climate change sceptic, Tony Abbott, to lead the Liberal Party (Economist, 2009).

The EU, despite the creation of a Climate Change Commissioner, has also seen climate change slip down the agenda because of the travails of the euro and the crisis in Greece. The perception of the EU as a global environmental actor (see Vogler, 2005) was also damaged irrevocably owing to splits within the EU, with countries such as Poland and even Germany reportedly blocking moves by Britain and others to put the cuts on the table. One summary read that the EU avoided the nightmare scenario of having to put its money where its mouth is by having its bluff called by the other participants, but that did not mean it avoided the embarrassment of not being able to shape a global agreement (Observer, 20 December 2009).

\section{Conclusions}

Overall, we argue that there has been a definite shift in the EU-Australia relationship since the dawn of the Rudd era. The hostile rhetoric of the Howard government in particular has given way to a new foreign policy rhetoric stressing multilateralism, partnership and common strategic objectives. This has been seen very clearly in the field of climate change. The decision to ask Kevin Rudd to act as a 'friend of the Chair' during the negotiations was in marked contrast to the actions of John Howard during previous world summits. As Raffin (2007, p. 23) argues, 'the focus in Canberra and Brussels has begun to shift from divergence to unity, from conflict to cooperation'. These healthy signs of new beginnings have been underscored by the recent appointment of Dr Brendan Nelson as Australia's next ambassador to the EU, which has been understood by some political commentators as a clear statement by Mr Rudd that the Brussels post is taken 'very seriously' in Canberra (Franklin, 2009). This is in turn reflected in some convergence in the environment domain, most 
obviously by means of the instruments chosen for climate mitigation, i.e. ETS, energy efficiency and investment in carbon capture and storage. However, two key points remain. This key area (environment and climate change) for cooperation has all the hallmarks of convergence but progress is stalled by domestic constraints, and thus hasty conclusions about the implications for the EU-Australia relationship must be avoided. The two policy positions put forward at COP15 (Conference of the Parties) showed the EU and Australia pretty much standing 'side by side' on this most important of issues.

Climate change therefore provided a litmus test for future collaborations on major issues such as the future of NATO, non-proliferation, trade liberalisation and the strengthening of the multilateral trading system. Australian support for EU moves to complete the Doha Round could once again be scuppered by agriculture, while Australian efforts to promote a new multilateral security mechanism for Asia and achieve a seat on the UN Security Council may run counter to EU interests. However, it appears likely that convergence in environmental matters will be mirrored by convergence in other key policy areas. The rise of the BRICs (Brazil, Russia, India and China) as global players alongside the impact of the global recession appears to have focused minds in capitals across the developed world. As Kevin Rudd noted; 'in the past, at a political level, Australia and Europe have concentrated on their divisions, not on the things they could do together'. The backdrop to Copenhagen was the global threat of climate change. However, alongside that it will highlight to what extent power relations between the developed and developing world have evolved since Kyoto in 1997. Whether Copenhagen represents the first public marginalisation of the EU and Australia on the global stage only time will tell, but their omission from the key moment shows that working together is likely to be the only future for the current Australian and EU administrations.

\section{Acknowledgements}

Very different versions of this paper were presented at the UACES Annual Research Conference, Zagreb, 5-7 September 2005, and the 47th Annual US ISA Convention, San Diego, 22-25 March 2006. Thanks are due to everyone who commented on our paper in those sessions, in particular Jenny Fairbrass, Dermot Hodson and Hanna Ojanen. Research for this paper was carried out while Simon Lightfoot was a visiting fellow at the National Europe Centre (NEC), Australian National University. He would like to thank the NEC for their support. He would also like to thank the Menzies Centre for Australian Studies for the award of an Australian Bicentennial Fellowship, which helped fund the trip. Finally, thanks are due to the British Council whose support part-funded the trip to Zagreb.

\section{Notes}

1. This article was written just before Kevin Rudd's exit as Prime Minister and so we have not been able to discuss the implications for EU-Australian relations of Julia Gillard becoming Prime Minister. A good early commentary on the new Prime Minister is provided by the Economist, 24 June 2010.

2. Reductions in emissions from land clearing is known as 'cheap carbon credits' because it requires little or no positive effort to achieve and does not involve reducing emissions from 'dirty' industries such as 


\section{K. Hussey and S. Lightfoot}

coal production. Instead, it relies on reducing or halting land clearing, which may have been reduced or halted anyway.

3. Article 174(2) states: 'Community policy on the environment shall aim at a high level of protection taking into account the diversity of situations in the various regions of the Community. It shall be based on the precautionary principle and on the principles that preventive action should be taken, that environmental damage should as a priority be rectified at source and that the polluter should pay.' In this context, harmonisation measures answering environmental protection requirements will include, where appropriate, a safeguard clause allowing member states to take provisional measures, for noneconomic environmental reasons, subject to a Community inspection procedure.

4. See Crowley (2007) for a fuller discussion of the domestic constraints on the Australian government when it comes to environmental policy.

\section{References}

Baker, S. (2005) Sustainable Development (London: Routledge).

Baker, S. (2006) Environmental values and climate change policy, in S. Lucarelli and I. Manners (Eds), Values and Principles in EU Foreign Policy (London: Routledge), pp. 77-96.

Brande, E. (2009) Green civilian power Europe?, in J. Orbie (Ed.), Europe's Global Role (Farnham: Ashgate), pp. 157-180.

Burchell, J. and Lightfoot, S. (2004) Leading the way: the EU at the WSSD, European Environment, 14(6), pp. 331-341.

Busch, P.-O. and Jorgens, H. (2005) The international sources of policy convergence: explaining the spread of environmental policy innovations, Journal of European Public Policy, 12(5), pp. 1-25.

Cass, L. (2008) A climate of obstinacy: symbolic politics in Australian and Canadian policy, Cambridge Review of International Affairs, 21(4), pp. 465-482.

CEC (2009) European Union-Australia Partnership Framework (Brussels: European Commission).

Costa, O. (2008) Is climate change changing the EU? The second image reversed in climate politics, Cambridge Review of International Affairs, 21(4), pp. 527-544.

Craft, H. (2009) Another chance for Rudd to lead the way in world affairs, The Age, 26 November, http:// www.theage.com.au/opinion/politics/another-chance-for-rudd-to-lead-the-way-in-world-affairs-20091126ju71.html, accessed 29 July 2010.

Crowley, K. (2007) Is Australia faking it? The Kyoto Protocol and the Greenhouse Policy Challenge, Global Environmental Politics, 7(4), pp. 118-139.

DeSombre, E. and Barkin, J. S. (2002) Turtles and trade: the WTO's acceptance of environmental trade restrictions, Global Environmental Politics, 2(1), pp. 12-18.

DFAT (2003) Australia and the European Union: An Agenda for Cooperation (Canberra: Commonwealth of Australia Publications).

Dobell, G. (2008) Europe welcomes Kevin Rudd's foreign policies, 3 April, http://www.abc.net.au/ra/ programguide/stories/200804/s2207535.htm, accessed 30 June 2010.

Eckersley, R. (2004) The big chill: the WTO and multilateral environmental agreements, Global Environmental Politics, 4(2), pp. 24-50.

Economist (2009) Coals from Newcastle, 6 June, http://www.economist.com/node/13782562, accessed 20 August 2010.

Economist (2010) Australia changes Prime Minister, 24 June, http://www.economist.com/node/ 16438698?story_id=16438698\&fsrc $=$ rss, accessed 20 August 2010.

Elliott, L. (2001a) Australia in world environmental affairs, in J. Cotton and J. Ravenhill (Eds), The National Interest in a Global Era (Melbourne: Oxford University Press), pp. 235-255.

Elliott, L. (2001b) Friends, allies or collaborators: environmental policy in the US-Australian relationship, Australian Journal of International Affairs, 55(2), pp. 261-273.

Franklin, M. (2009) Kevin Rudd sends former foes Kim Beazley and Brendan Nelson into battle, The Australian, 18 September, http://www.theaustralian.com.au/news/nation/kevin-rudd-sends-former-foeskim-beazley-and-brendan-nelson-into-battle/story-e6frg6nf-1225776326156, accessed 20 October 2009.

Grant, R. and Papadakis, E. (2004) Challenges for global environmental diplomacy in Australia and the European Union, Australian Journal of International Affairs, 58(2), pp. 279-292.

Howard, J. (2005) Australia-EU relations: shared interests, common challenges, European View, 2, pp. $77-83$. 
Hussey, K. (2007) An examination of the European Union as an environmental leader in global environmental governance, unpublished PhD thesis, University of Melbourne.

Kellow, A. (2006) A new process for negotiating multilateral environmental agreements? The Asia-Pacific climate partnership beyond Kyoto, Australian Journal of International Affairs, 60(2), pp. 287-303.

Kenyon, D. and Kunkel, J. (2005) Australia and the European Union in the world trade organisation, Australian Journal of International Affairs, 59(1), pp. 55-69.

Lafferty, W. (1997) The politics of sustainable development, Environmental Politics, 5(2), pp. 185-208.

Lawrence, P. (2009) Australian climate policy and the Asia Pacific partnership on clean development and climate (APP). From Howard to Rudd: continuity or change, International Environmental Agreements: Politics, Law and Economics, 9(2), pp. 281-299.

Lightfoot, S. (2006) A good international citizen? Australia at the World Summit on Sustainable Development, Australian Journal of International Affairs, 60(3), pp. 457-471.

McDonald, M. (2005) Fair weather friend? Australia's approach to global climate change, Australian Journal of Politics and History, 51(2), pp. 216-234.

McGee, J. and Taplin, R. (2006) The Asia-Pacific partnership on clean development and climate: a complement or competitor to the Kyoto protocol? Global Change, Peace \& Security, 18(3), pp. 173-192.

McGee, J. and Taplin, R. (2009) The role of the Asia Pacific Partnership in discursive contestation of the international climate regime, International Environmental Agreements: Politics, Law and Economics, 9(2), pp. 213-238.

Murray, P. (2005) Australia and the European Superpower: Engaging with the European Union (Melbourne: Melbourne University Press).

Oberthür, S. and Kelly, C. R. (2008) EU leadership in international climate policy: achievements and challenges, The International Spectator, 43(3), pp. 35-50.

Oxley, A. (2002) Free Trade Agreements in the Era of Globalization: New Instruments to Advance New Interests: The Case of Australia, Australian APEC Study Centre Issues Paper No. 22.

Pallermaerts, M. (2003) The World Summit on Sustainable Development: environment, precaution and trade - a potential for success and/or failure, RECEIL, 12(1), pp. 12-22.

Papadakis, E. (2002) Global environmental diplomacy: Australia's stance on global warming, Australian Journal of International Affairs, 56(2), pp. 265-277.

Pearce, F. (2009) Australia's Copenhagen climate strategy is smoke and mirrors, The Guardian, 26 November, http://www.guardian.co.uk/environment/cif-green/2009/nov/26/australia-emissions-copenhagengreenwash-rudd, accessed 20 October 2009.

Raffin, L. (2007) Indivisible partners or enduring combatants? Divisions and triumphs in the EUAustralian relationship, Journal of Contemporary European Research, 3(2), pp. 1-23.

Stevenson, H. (2009) Cheating on climate change? Australia's challenge to global warming norms, Australian Journal of International Affairs, 63(2), pp. 165-186.

Vogler, J. (2005) The European contribution to global environmental governance, International Affairs, 81(4), pp. 835-850.

WCED (1987) World Commission on Environment and Development: Our Common Future (Oxford: Oxford University Press). 